\title{
URBAN GEOMORPHOLOGICAL HERITAGE. AN OVERVIEW
}

\author{
Emmanuel Reynard ${ }^{1}$, Alessia Pica ${ }^{2}$, Paola Coratza ${ }^{3}$ \\ ${ }^{1}$ Institute of Geography and Sustainability, University of Lausanne, Switzerland \\ ${ }^{2}$ Department of Earth Sciences, Sapienza University of Rome, Italy \\ ${ }^{3}$ Department of Chemical and Geological Science, University of Modena and Reggio Emilia, Italy \\ Manuscript received: May 08, 2017 \\ Revised version: July 10, 2017
}

\begin{abstract}
Reynard E., Pica A., Coratza P., 2017. Urban geomorphological heritage. An overview. Quaestiones Geographicae 36(3), Bogucki Wydawnictwo Naukowe, Poznań, pp. 7-20. 4 figs, 1 table.

AвSTRACT: Urbanization is a global phenomenon and currently more than half of the world's population lives in urban areas. Studies on geomorphological heritage and the development of specific methods of investigation (assessment, inventories, cartography) are, however, relatively rare and limited. This paper first describes the relationships between urbanization and geomorphology. Secondly, it presents an overview of the main works on the urban geomorphological heritage. Then, the main methods of investigation are presented. Finally, we discuss the challenging issues concerning the protection and the promotion of the urban geomorphological heritage.
\end{abstract}

KEY WORDS: geomorphology; geomorphological heritage; urban areas; urban geomorphology; geomorphosites

Corresponding author: Emmanuel Reynard,emmanuel.reynard@unil.ch

\section{Introduction}

Urbanization is one of the major challenges that the world faces. At least $0.5 \%$ of the terrestrial area is now urbanized (Schneider et al. 2009). In $2015,54 \%$ of the world population was living in urban areas and in some countries this percentage is close to $100 \%$ (Singapore 100\%; Qatar 99\%; Belgium 98\%; Kuwait 98\%; Iceland 94\%; Japan 93\%; Argentina 92\%; The Netherlands 90\%; Chile 90\%; Data: World Bank). In several parts of the world annual urbanization rates exceed 5\% (e.g. Oman 8.54\%; Rwanda 6.43\%; Burkina Faso $5.87 \%$; Uganda 5.43\%; Burundi 5.66\%; Tanzania $5.36 \%$; Niger 5.14\%; Data: CIA), which means that urban sprawl is a widespread phenomenon. Urbanization and correlated infrastructure building highly impact and sometimes completely destroy landforms.

Geomorphological research - and geomorphological heritage analyses in particular - has traditionally been carried out in rural or natural areas. For long, geomorphological studies in urban areas have remained less developed. Nevertheless, urban areas are particularly interesting from a geomorphological point of view for three reasons:

1. the geomorphological context (site) of some cities (Onde 1966) is part of their "image" and their fame (e.g. the sugarloaf mountains of Rio de Janeiro);

2. urban sprawl often interacts with geomorphological processes (e.g. landslides) and landforms (e.g. fluvial or coastal forms), and necessitates specific methods to deal with geomorphological processes (Mohapatra et al. 2014);

3. cities are often tourist destinations, and there is a potential for geotourist popularization of their geomorphological heritage (Reynard et al. 2015). 
Based on a bibliographical review, this paper addresses the main challenges of research on geomorphological heritage in urban contexts:

1. the definition and characterization of urban geomorphological heritage;

2 . the complex interrelations between natural landforms and urbanization (e.g. the partial or total invisibility of landforms and sediments that are covered or destroyed by urban infrastructures; man-made landforms as part of urban geomorphological heritage; the suitability of some landforms (valleys, gullies, mounts) for specific urban uses; the geomorphic constraints imposed by landforms and geomorphological processes on urban development; the importance of some landforms in the urban landscape and the image of the cities);

3 . the various methods developed for describing, mapping and assessing urban geomorphological heritage;

4. the challenges concerning conservation and promotion of urban geomorphosites (geotourism), in particular the relationships between geomorphological and cultural or archaeological heritage, and possible synergies in their tourist promotion.

\section{Definition and characterization of urban geomorphological heritage}

Urban geomorphological heritage refers to two fields of research: (i) urban geomorphology; (ii) geomorphological heritage.

Urban geomorphology examines geomorphic constraints on urban development (Cooke 1984), suitability of different landforms for specific urban uses, the impact of urban activities on Earth surface processes, landforms created by urbanization, and geomorphic consequences of extractive industries in and around urban areas (McCall et al. 1996, Douglas, James 2015, Thornbush 2015). It developed in the 1970s (Cooke 1976), with studies on specific geographical contexts - such as dry lands (Cooke et al. 1982) - or thematic fields - such as urban geomorphic hazards (Cooke 1984) or urban rivers (Wolman 1967, Chin 2006, Chin et al. 2013). A large set of research has addressed the question of impacts of human activities - e.g. urbanization - on geomorphological processes and landforms, i.e. anthropogenic geomorphology (Douglas 2005, Szabó et al. 2010, Ellis 2011, Tarolli, Sofia 2016).

Currently, urban geomorphology addresses new questions such as ecosystem services provided by geomorphological processes and landforms (Picket et al. 2001, Gordon et al. 2012, Gray et al. 2013), interconnections between geomorphological and anthropogenic systems, studied through holistic approaches, and the need to merge physical geography and human and social sciences approaches, giving rise to new hybrid approaches such as socio-hydrology (Sivaplan et al. 2012) or critical physical geography (Lave et al. 2014). Also the emergence of the Anthropocene as a new interval of geological time in which human influence on Earth dominates over natural processes (Steffen et al. 2011) has induced new researches in geomorphology specifically addressed to the analysis of Man/Earth interaction challenges (Price et al. 2011, Goudie and Viles 2016, Brown et al. 2017).

Geomorphological heritage is the set of landforms worthy of being protected and transmitted to the future generations (Reynard 2009). As other types of geoheritage (palaeontological, mineralogical, etc.) it is mainly constituted of monothematic sites: geomorphosites (in situ geomorphological heritage) i.e. landforms and landscapes (Reynard 2005a) that the society considers as part of the heritage of an area (Coratza, Hobléa 2017). Giving a value to landforms is part of a complex social process of "heritage making" (Reynard et al. 2011, Coratza, Hobléa 2017). Historically, the definition and assessment of geomorphosites have been made by geoscientists, who have considered different types of values: the intrinsic value for Earth history reconstruction and Earth dynamics knowledge, and several societal (or use) values, for example for cultural, economic or educational reasons (see Reynard, Coratza 2013 or Brilha 2016 for a review).

After the quality of geomorphosites has been recognized they need to be managed. The conservation of the geomorphological heritage implies the adoption of rules allowing their protection, both physical (e.g. fences, protection) and institutional (public policies, property or access right restrictions, Reynard 2005b). The promotion and popularization of geomorphological heritage is made through interpretation (Tilden 1957, Gross, Zimmermann 2002, Martin 2014) and geotourism 
(Hose 1995, 2012, Dowling, Newsome 2006), for which several methods and tools have been developed (e.g. Martin et al. 2010, Cayla 2014).

\section{The complex interrelations between natural landforms and urbanization}

Geomorphology interacts in various ways with cities and urbanization (Figs 1 and 2). Six types of relations may be delineated (see letters in Fig. 1):

a) Landforms contribute to the landscape and natural heritage of cities (Fig. 1a). They sometimes participates to the "image" - or the fame - of the city. Thus, the landscape of Rio de Ja-

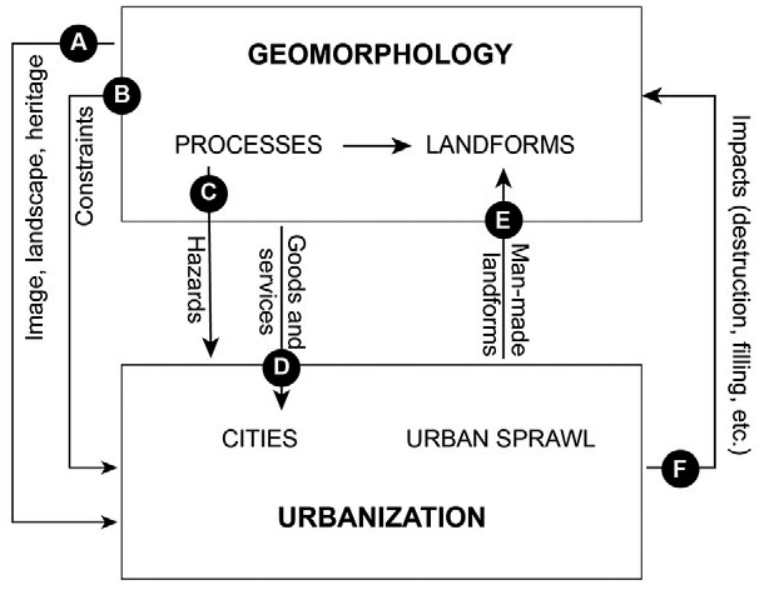

Fig. 1. Relationships between geomorphology and urbanization. neiro, Brazil, is inseparable from the sugarloaf
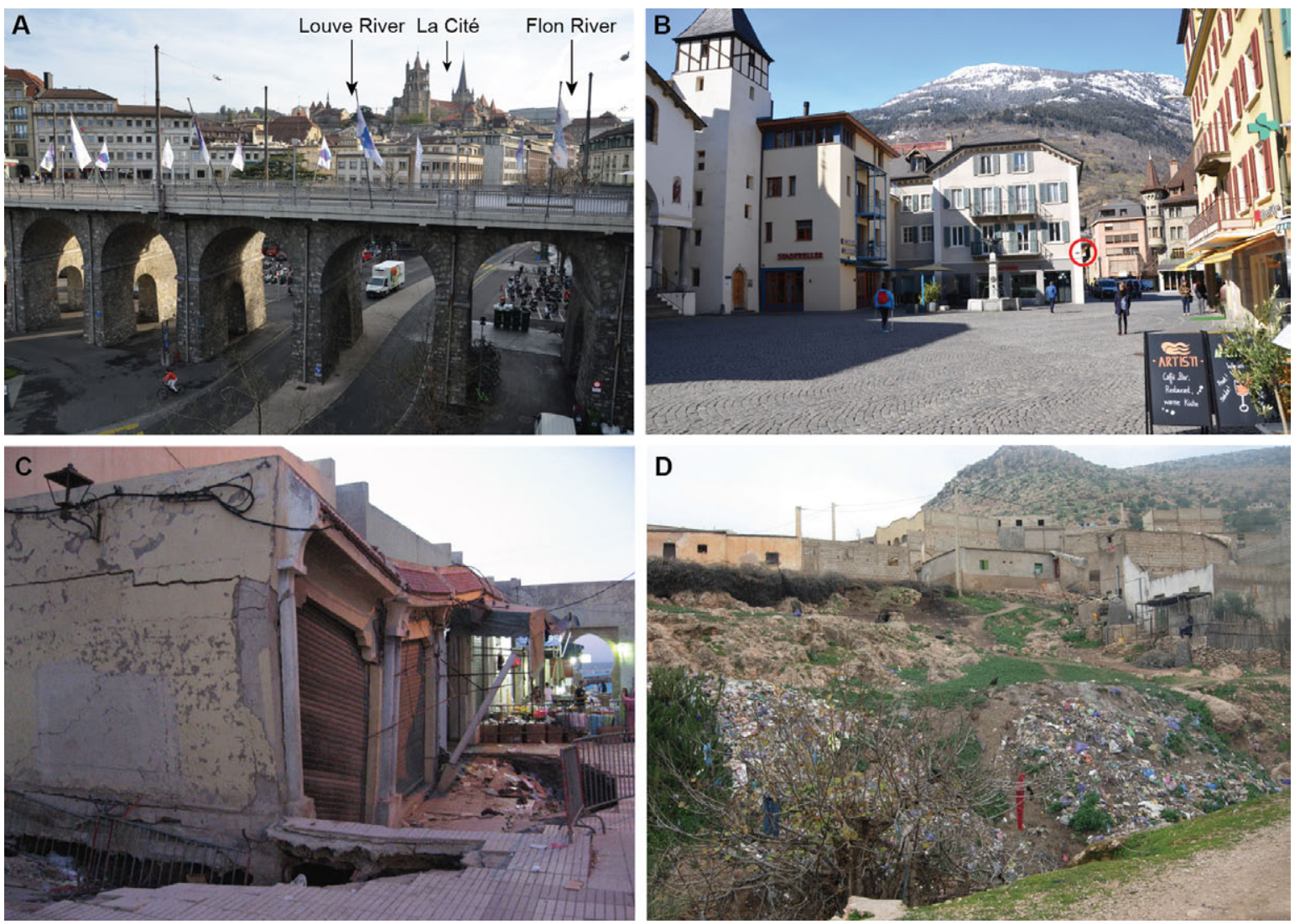

Fig. 2. Example of relationships between geomorphology and urbanization.

a) Centre of the city of Lausanne, Switzerland: the Middle Ages town (La Cité, with the cathedral) developed on a molassic hill, which was a defensive site isolated by two rivers; during the 19th century the rivers were covered and the valleys partly infilled with sediments to facilitate mobility; b) The city of Brig, Switzerland, was impacted by an intense debris flow event in 1993; the red circle indicates a sign recording the height of the sediments transported during this event; c) Beni Mellal, Morocco is located on a complex of alluvial fans and travertine deposits at the piedmont of the High Atlas; historically caves were installed in the travertine deposits to store food and other materials and now the centre is affected by collapses due to the dissolution of travertine deposits because of water infiltration; d) A view of the suburbs of Beni Mellal, Morocco, where the gullies and river beds are used to store wastes, which are then eroded by the river and transported on the alluvial fans, on which the city is located, where they sediment

together with other rock materials transported by the river (Photo: E. Reynard). 
landforms due to selected weathering and erosion of granite rocks under tropical climate (Fernandes et al. 2010), while the image of Cape Town, South Africa, is strongly marked by the sandstone plateaus and the granite batholith that surround the city (Meadows, Compton 2015) and Edinburgh historical centre, in particular the castle, is built on a typical crag-andtail morphology (Halsall 2000). Sometimes the geomorphological image is dependent of the reliefs viewed from the city (e.g. Mount Fuji seen from Tokyo, the Vesuvius seen from Naples or the Puy de Dôme volcano seen from Clermont-Ferrand, France, Boivin, Thouret 2014). More than anywhere else, in tourist towns the view on the reliefs plays a major role on town planning, especially on the price of land and housing (e.g. the view towards Mont Blanc in Chamonix, France, or Matterhorn, in Zermatt, Switzerland). At smaller scales, the image of certain city districts stems from the geomorphological context (e.g. Montmartre hill in Paris, which is a butte-witness of the cuestas of the Paris basin, or the historical town of Bern, Switzerland, nestled in a meander of the Aare River and classified as a UNESCO World Heritage site).

b) Landforms may also constitute a constraint to urban development (Figs $1 \mathrm{~b}$ and 2a). Sometimes, it is the boundary between two geomorphological contexts that prevents urbanization in certain directions, e.g. in seafronts or plateau edges (Cape Town). The French town of Clermont-Ferrand stretches for more than $40 \mathrm{~km}$ along the slope separating the Limagne depression from the Puys volcanic chain (Jamot 2001). The slope is also a constraint to urbanization and it induces natural hazards, such as landslides, rockslides or debris flows, particularly hazardous in settlements developed without planning on unstable slopes under humid climates. This is the case of many slums in developing countries. Some specific geomorphological contexts also give rise to important urban planning constraints. The lagoon context of Venice imposed a specific urban model, the streets being replaced by canals (Bondesan 2017). Mexico City, which has spread over drained marshes, faces major problems of instability due to the collapse of former marshlands and the overexploitation of groundwater (Ortega-Guerrero et al. 1999, Ortiz-Zamora, Ortega-Guerrero 2010, Siles et al. 2015).

c) Geomorphological processes may lead to natural hazards (Figs 1c, 2b and 2c). In urban areas, damages and losses are much greater than in rural areas because of the concentration of people that increases vulnerability. In 1985, the town of Armero, Colombia, was largely destroyed by a lahar caused by the eruption of Nevado del Ruiz volcano, causing 24,000 deaths, in 1999, a series of landslides due to torrential rains - known as the Vargas tragedy - killed 20,000 people in the slums of Caracas in Venezuela. Other cities are particularly vulnerable to earthquakes (San Francisco, Japanese cities, historical cities of central Italy, Lisbon, destroyed in 1755, etc.), flooding (Chinese cities along the Yellow River or Yangtze River, the cities of the Netherlands or the Danube basin, etc.), storms (almost all coastal cities, e.g. New Orleans, partly destroyed by Hurricane Katrina in 2005). Beyond these exceptional events, most cities are recurrently confronted with the dynamics of geomorphological processes that affect urban management in the form of small landslides, rockslides or floods. Subsidence processes due to the exploitation of underground resources are quite common (Sherlock 1922), as is the case of water extraction in Mexico City (Ortega-Guerrero et al. 1999, Ortiz-Zamora, Ortega-Guerrero 2010) or coal exploitation in Europe (Price et al. 2011, Lamich et al. 2016). Also natural subsidence due to dissolution processes in soluble rocks, such as limestone, dolostone or travertine, may create hazardous situations in cities. In highly urbanized areas natural sinkholes are often buried by anthropogenic deposits and infrastructures creating situations of acute risk due to the invisibility of process activity at the surface (Billi et al. 2016). Absence of planning measures and neo-liberalization of urban space - as was the case of post-war period in Sarajevo, Bosnia and Herzegovina - may increase the level of geomorphic risk (Martín-Díaz et al. 2011).

d) Geomorphology - like other components of the natural environment - provides cities with ecosystem goods and services (Figs 1d and $2 \mathrm{~d}$ ). Some geomorphological contexts offer 
supply services. Number of rock outcrops are, or have been, sites of extraction of building stones (Přrikryl, Török 2010); the same applies to unconsolidated sediments (sand, gravel, clay) exploited by gravel pits. In some regions (Belgium, Northern France, England) cities organized around coal exploitation. Other geomorphological contexts are aquifers used for drinking water supply. Certain landforms are suitable for particular uses. Promontories, mounds and hills, sometimes isolated by rivers, have been used by many cities as defensive sites, especially during the Middle Ages in Europe. They also provide services as viewpoints (Migoń, Pijet-Migoń 2017). In contrast, valleys and ravines are generally used for industrial purposes, to take advantage of hydraulic power. Depressions are often used as places for various deposits (Price et al. 2011, Adeli, Khorshiddoustb 2011). As most of European cities during their process of industrialization, Vienna highly used the Danube River landforms and sediments, as supply of materials and as receptacles for wastes (Gierlinger et al. 2013). In Great Britain geomorphological transformations due to human activity were particularly intense during the phase of industrialization beginning in the late 18th century (Price et al. 2011), which "resulted in the large-scale creation of artificial ground". On the other side, geomorphology also offers a variety of amenities for city dwellers: cornices are used as walking spots, as are mounds and banks of rivers or lakes.

e) Urbanization is a vector of relief transformation. Artificial landforms are thus created (Fig. 1e). These are often infillings designed to eliminate slopes and to facilitate mobility. They are also hills formed of various waste materials. The terrils of the mining basins of north-western Europe (e.g. Charleroi, Belgium) are an example of artificial landforms. Sometimes artificial landforms are created at the expense of the sea (the Zuiderzee polder in the Netherlands, the artificial islands of Palm Islands, Dubai) or lakes. Protective structures against natural hazards - e.g. dikes along rivers - are other examples of newly created artificial forms. Price et al. (2011) proposed a classification of artificial grounds based on a morpho-stratigraphic approach; five cat- egories or artificial grounds are delineated: made grounds (areas where material has been placed by humans on the pre-existing land surface); worked grounds (areas where the pre-existing land surface has been excavated); infilled grounds (areas where the pre-existing land surface has been excavated and then partially or totally backfilled); disturbed grounds (associations of excavated, subsident and spoiled material); and landscaped ground (remodelled morphology). The latter is frequent in urban parks and gardens (Wilczkiewicz 2016), a practice that historically developed in China and Japan and then spread off in other countries and cities. Landform designing may take into account three main factors: the integration of the artificial forms with the surrounding landforms; the viewpoint design; and the composition of a view with visual objects (for example landforms) (Yamaguchi et al. 2008).

f) Finally, urbanization is a factor of modification, even destruction, of landforms (Fig. 1f). Numerous landforms are affected by town planning, notably by various fillings, perforations (tunnels) or abrasions. It results in partial or total invisibility of landforms and sediments that are covered or destroyed by urban infrastructures. The most eloquent example is the program of mountain flattening carried out in China to build new cities, which creates several hydrological and geomorphological impacts such as landslides, subsidence and soil erosion ( $\mathrm{Li}$ et al. 2014). Another example is Seattle city, studied by Williams (2015). Douglas and Lawson (2001) estimated that at the global scale the volumes of material removed and transported during anthropogenic works exceed by almost a factor three the volumes of sediments transported to the oceans by rivers. At lower scales, impacts are recurrent in all cities of the world. They mainly concern fluvial landforms, by river training works, coastal landforms, strongly affected by anti-erosion structures, steep landscapes, which are often disturbed by flood and slope hazard protection works, and depressions, widely used as receptacles for various deposits.

Urban geomorphological heritage is part of relation A (Fig. 1) and is represented by geomorphosites (Panizza 2001, Reynard et al. 2009). 
Table 1. Two categories of urban geomorphosites.

\begin{tabular}{|c|c|c|}
\hline & Urban geomorphosite lato sensu & Urban geomorphosite stricto sensu \\
\hline Definition & $\begin{array}{l}\text { Any geomorphosite (landform con- } \\
\text { sidered as geoheritage by the society) } \\
\text { situated within the limits of the urban } \\
\text { space }\end{array}$ & $\begin{array}{l}\text { Locality that helps understanding the interac- } \\
\text { tions between geomorphology and urban devel- } \\
\text { opment (see the six types of relations in Fig. 1) }\end{array}$ \\
\hline Examples & $\begin{array}{l}\text { Erratic boulders or roches moutonnées } \\
\text { that are testimonies of former glacia- } \\
\text { tions and that are situated within the } \\
\text { limits of a town }\end{array}$ & $\begin{array}{l}\text { Traces in the street network of former channels } \\
\text { of a braided river that has been embanked (the } \\
\text { form of the street network remembers the form } \\
\text { of the natural channels; relation F, Fig. 1) }\end{array}$ \\
\hline
\end{tabular}

Some are spectacular whereas other are much less visible and known and can be easily damaged due to urban works and urban sprawl. A distinction is made between 'ordinary' geomorphosites located within the town's limits (e.g. the Glacier Garden in Lucerne, Switzerland - a locality with glacial potholes and erratic boulders; roches moutonnées in Central Park, New York) and those sites that are important because they illustrate the interactions of urbanization with geomorphology (Table 1). Urban geomorphosites in a strict sense are localities that show the interactions between geomorphology and urban development (Fig. 1) and that help understanding:

1. the magnitude of landscape transformation due to urbanization (relation E, F; Fig. 1);

2. the geomorphological constraints on urban space development (relation B);

3. hazards due to poorly controlled urban expansion (relation C);

4. goods and services provided to the city by landforms, including amenities and urban facilities (relations A and D). Urban geomorphosites in a large sense are 'ordinary' geomorphosites located in urban contexts.

Urban geomorphosites should be considered, analysed and managed as other types of geomorphosites located in rural land and natural areas. As any type of geomorphosites, they may be isolated or groups of landforms, complex of landforms or geomorphological systems (following the typology of Grandgirard 1997). Examples of isolated or groups of landforms are the numerous erratic boulders scattered in towns in Europe or North America. They are often removed from their original position because of urban works and sometimes used as urban monuments, a situation which addresses the question of the loss of their scientific importance, principally based on their location as markers of former glacier advances. Karstic features (sinkholes, karren fields, precipitation landforms, karstic springs) are examples of groups of landforms (several landforms due to one process) that may be considered as complex geomorphosites in cities located in carbonate environments. Numerous cities are situated in complex geomorphological settings, including various processes, and the urban site itself may be considered as a geomorphosite (geomorphological system). Examples are the geomorphology of Geneva, Switzerland, highly influenced by a combination of structural factors and glacial and postglacial history of the Rhone glacier (Moscariello 2017), or Lyon, which results of a complex interaction of tectonic and fluvial processes (Bravard 1997). Urban geomorphosites can be either dynamic (active geomorphosites) or inactive (i.e. representative of past morphodynamic conditions not existing any more); some can be evolving passive geomorphosites (following the typology of Pelfini, Bollati 2014).

Urban geotourism is recent. Some pioneering example works are from London in the 1980s, when geological walks were proposed (Robinson 1982, 1984, 1985). In the following years several aspects were addressed, in particular: the origin of building stones used in historical monuments (Gomez-Heras et al. 2010, Perez-Monserrat et al. 2013, Borghi et al. 2014, Del Lama et al. 2015); geological/geomorphological features of the natural site on which a city is built (Côté et al. 2009, Rodrigues et al. 2011, Del Monte et al. 2013, Pica et al. 2016); the links between geoheritage and archaeological heritage (Dóniz-Páez, BecerraRamírez 2015, Palacio Prieto 2015); and geotourism mapping (Côté et al. 2009, Pica et al. 2016). Urban areas also provide interesting contextual conditions for developing geotouristic products (Reynard et al. 2015, Pica et al. 2017), based on geo-interpretation (Martin et al. 2010, Hose 2012). An original geotouristic approach is the one focused on the problem of subsidence of historical 
churches in Ostrava-Karvina District (Czech Republic) due to coal mining. Lamich et al. (2016) propose to develop a geotouristic project showing various examples of subsidence, with the aim of explaining the geomorphological and geotechnical reasons of the churches' subsidence.

\section{Methods for investigating urban geomorphological heritage}

The methodological approach for the analysis of urban geomorphological heritage is varying depending on the objectives of studies. Fundamental are methods aimed at integrating survey data, historical maps, aerial photographs and archaeological findings (e.g. Kasprzak, Traczyk 2014, Del Monte 2016). The analysis of historical changes can help understanding how geomorphology ruled transformations and how it will do so in the future (Stäuble et al. 2008).

One of the principal methods of investigation is based on the geohistorical reconstruction aiming at the comparison of early landscape data with recent ones, which was used in different urban geomorphological studies (Cousins 2001, Shimizu and Fuse 2003, James et al. 2012, San-Antonio-Gómez et al. 2014, Lucchesi and Giardino 2015, Del Monte et al. 2016). The overlay of historical maps in a GIS environment enables comparison, spatial analysis and quantification of landscape changes due to urbanization. The digitization of territorial features allows the quantification of changes over time (appearance and disappearance of elements, Stäuble et al. 2008, Baud and Reynard 2015, Clivaz and Reynard 2017). This approach was particularly used for the reconstruction of river landscape evolution in urban contexts; among the numerous studies are the works on the Danube River in Vienna (special issue of Water History, 2013, in particular Winiwarter et al. 2013, Hohensinner et al. 2013a, b, Haidvogel et al. 2013), on the Garonne River in Toulouse, France (Valette, Carozza 2013) or on the Rhone River in Lyon, France (Bethemont, Bravard 2014).

Geomorphological mapping in urban contexts is not easy and adaptation of standard methods used in natural contexts (Smith et al. 2011) is needed. The analysis of aerial photographs and maps over time allows mapping geomorphological and drainage network changes due to the anthropogenic activity and new symbols need to be created to represent anthropogenic landforms and processes (Del Monte et al. 2016). Very few examples of extensive geomorphological maps in urban contexts exist. The Rome Geomorphological Map (Del Monte et al. 2016; Fig. 3) is one of the rare examples of geomorphological map of a metropolis. Similar methods have been used to map anthropogenic transformations of cities (Lucchesi, Giardino 2015, Mozzi et al. 2016).

The analysis of urban geomorphosites themselves is multidisciplinary and combines various approaches:

- interpretation of multi-temporal aerial photographs and digital terrain models (DTM) (Del Monte et al. 2013, 2016);

- consultation of geological and geotechnical investigations (drillings, quantification of landfills, Jordan et al. 2014, Del Monte et al. 2016);

- analysis of hydrogeological maps (telling about landscape changes for water regulation);

- comparison with historical-archaeological data and archive documents (Del Monte et al. 2013, Clivaz, Reynard 2017);

- review of historical iconography and consultation of historical press (photographs and landscape paintings, news about releases of major urban works; Del Monte et al. 2016, Clivaz, Reynard 2017)

- field geomorphological survey

- geomorphological mapping

- assessment of geomorphosites

Few examples of urban geomorphological heritage inventories or assessment exist. An example is from Rome (Pica et al. 2016), and some case studies from the Mediterranean and middle European areas are reported in this volume. The application of standard methods for geomorphosite assessment (see Reynard, Coratza 2013 and Brilha 2016 for a review) is not effective in urban areas. In fact, the characteristics of urbanized areas (buildings, landscape anthropogenic transformations, etc.) often hide landforms or have completely or partially erased them, which impacts on their integrity (which is one of the main criteria generally used to assess the scientific importance geomorphosites) or their aesthetic value (often considered as an additional value of geomorphosites). A specific method for urban 


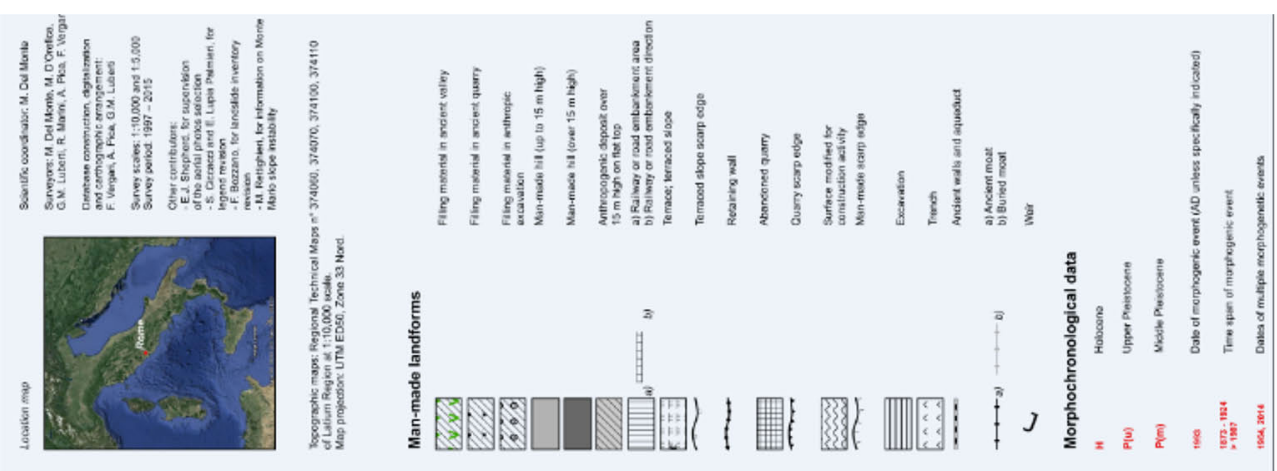

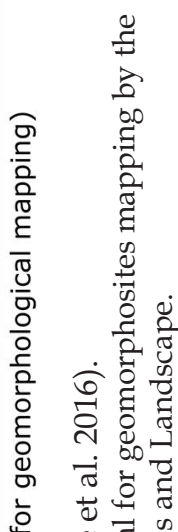

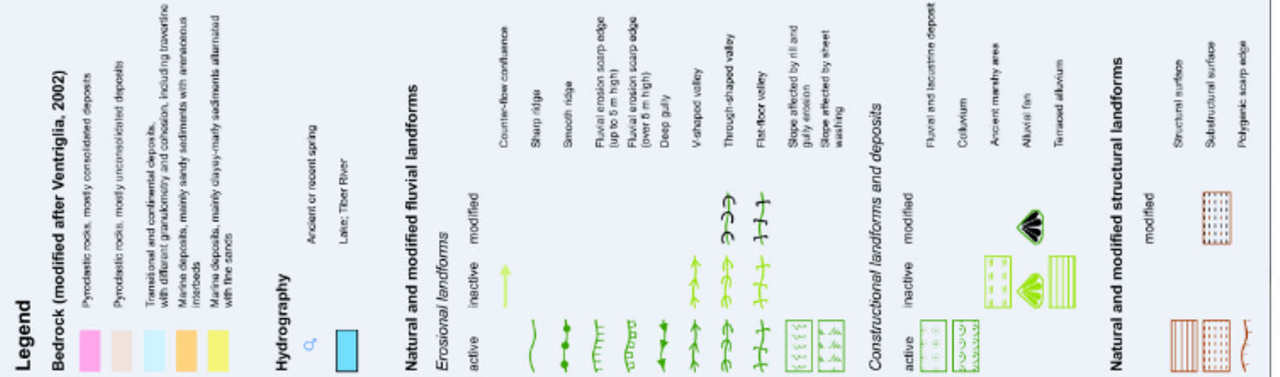

蕓.

造 월

$\vec{\nabla} \approx 0$

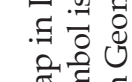

छี है

웡 है

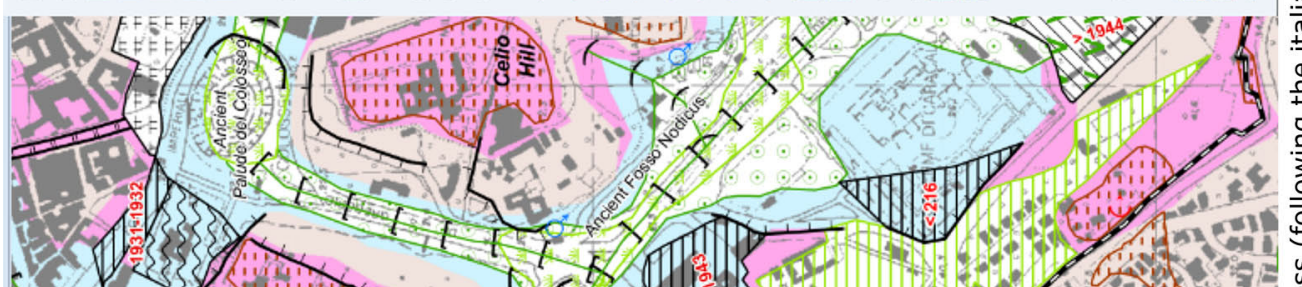

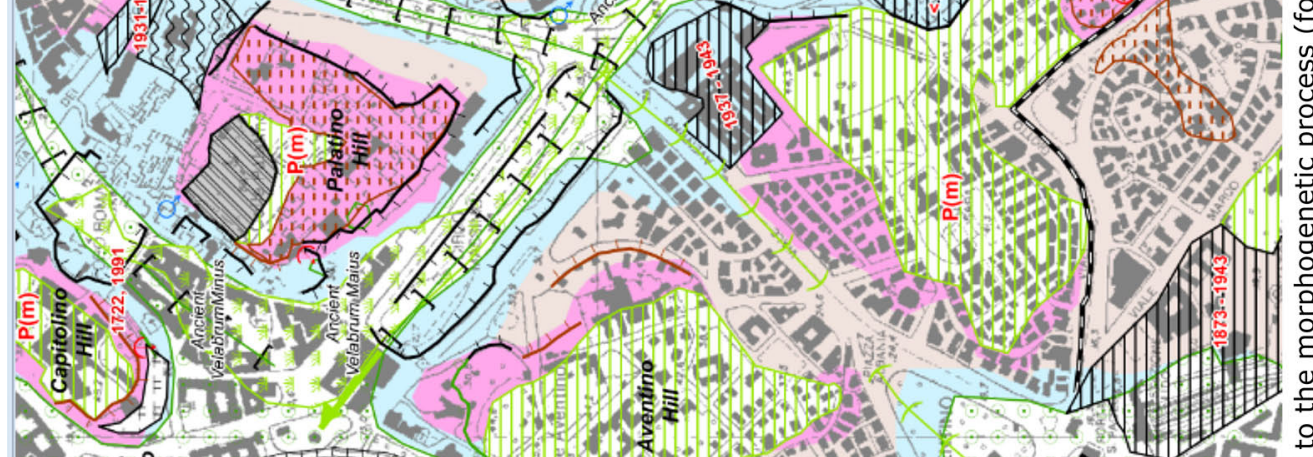

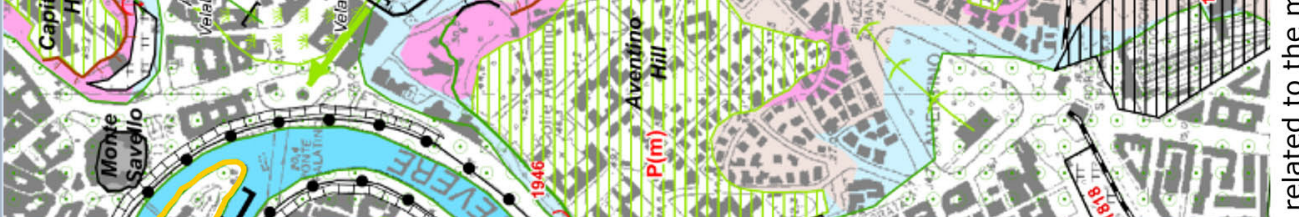

3 .

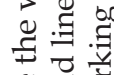

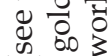

2.

范过

đ

6.

웜

क्षे क्षे

苛

$\infty_{0}=0$

응 है 듬

은

हैं क्षे

¿ 8

हี ซ

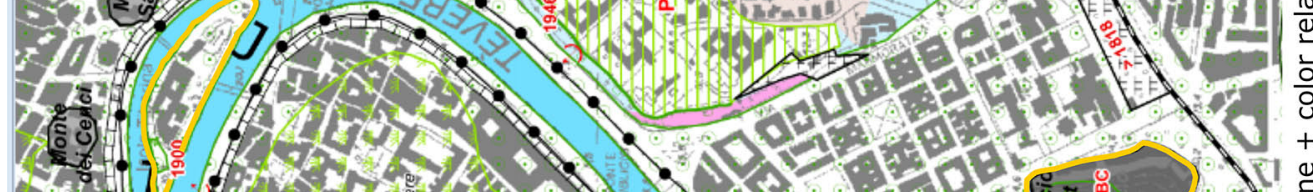

x.m.
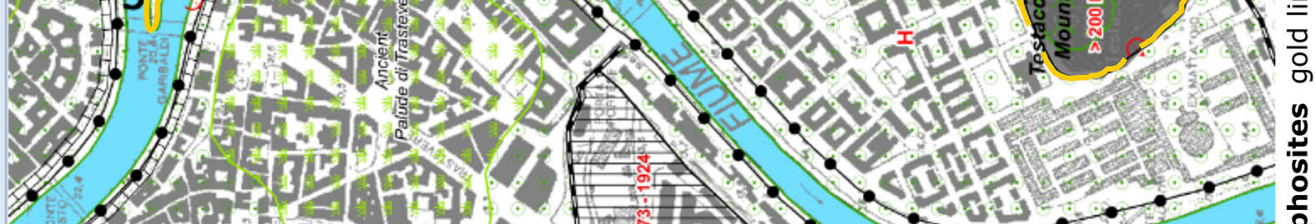

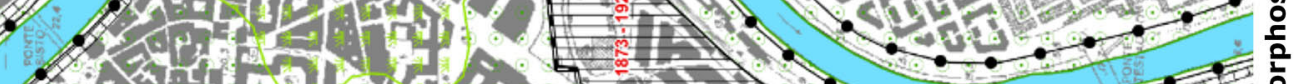

1.5. 15.

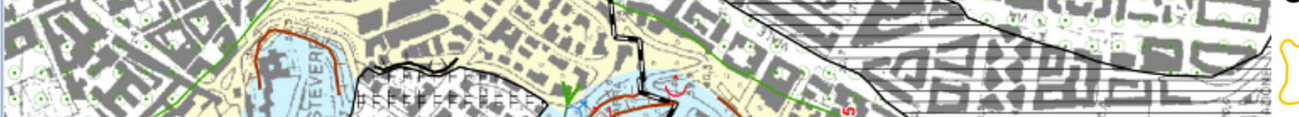

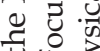
虫 동 胥 « i

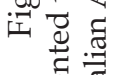


geomorphosite assessment is, therefore, needed, which takes into account hidden, destroyed and invisible landforms (Clivaz, Reynard 2017) as well as man-made ones (anthropogenic landforms). However, many elements in the already known assessment methods are difficult to use: it is not easy to assess the scientific representativeness and the rarity of something no longer existing; so is it about the aesthetic value of an invisible site, or even the accessibility of places difficult to localize.

Some researchers suggested solutions for interpreting urban geomorphological heritage: augmented reality and 3D reconstructions (Cayla 2014) or interpretive images (Pica et al. 2017). One advantage of digital technologies is their multifunctionality that allows some basic needs in geoheritage studies: geolocation, mapping and visualization (Cayla 2014, Martin et al. 2014). They also allow proposing reconstructions of ancient landscapes inserted on current urban landscape photographs (Pica 2017).

\section{Challenges concerning the conservation and the promotion of urban geomorphosites}

The protection of the urban geomorphological heritage faces several challenges:

- As mentioned above, landforms are often modified, sometimes destroyed and very often covered by urban infrastructures. Urban geomorphosites are vulnerable to the impacts of human activities. They should therefore be particularly protected in order to avoid their alteration or destruction. This objective needs the development of methods for their inventory, assessment and mapping.

- Moreover, urban landforms are difficult to spot on the ground because they are often covered. Thus, evaluation using conventional geosite assessment methods is difficult to implement. In addition, with some exceptions (Pica et al., 2016), there are extremely few systematic geosite inventories in urban areas. As a result, their protection is poorly developed.

- In rural and natural environments, the protection of geoheritage is often indirect, through the protection of biological or landscape values or by the definition of protected areas of a certain size, such as national parks, regional nature parks or biosphere reserves (Reynard et al., 2009). As natural protected areas are rare in urban contexts, the indirect protection of geomorphological heritage by this type of protected areas is itself poorly developed.

However, this is compensated by indirect protection through historical heritage, which prevents changes of buildings and infrastructure (e.g. historical centres) and is indirectly applied to terrain configuration. The urban geomorphological heritage may therefore be partially protected through its interactions with the cultural heritage. Historical monuments and historic districts often enjoy some protection. Since they are sometimes located in particular geomorphological sites (cornices, hills, high points, etc.), the geomorphological context is in fact protected. The same is true of geomorphological sites that coincide with archaeological remains. Nevertheless, these means of indirect protection remain limited and do not cover by far all the urban geomorphosites. Therefore, it is important that geomorphologists now apply their methods of investigation (assessment, mapping, inventories) to urban contexts, as they have done for two decades in natural and rural environments.

In some cases the historical importance of landscape elements and landforms led to its conservation by man-made infrastructures. For example the Tiberina Island in Rome is a fluvial isle and its boundaries are protected against fluvial erosion by travertine embankments (Fig. 4). Since the Roman period the landform has been useful bridging the Tiber River and it had a legendary importance as a symbol of Roman medicine god (Pica et al. 2016). The embankments conserve a boat shape calling to mind the Esculapio (medicine god) boat coming from Greece to save Romans from pestilence. This example encourages the selection and promotion of landforms as geomorphosites, because giving importance to the sites helps to make understandable its significance as natural and human history testimony.

With regard to the popularization of urban geoheritage, especially through geotourism, there are still some issues that can be highlighted. First of all, the question of the public arises. We hypothesize that some urban tourists who like to discover the historical heritage (monuments, development of the city) could also be a potential 


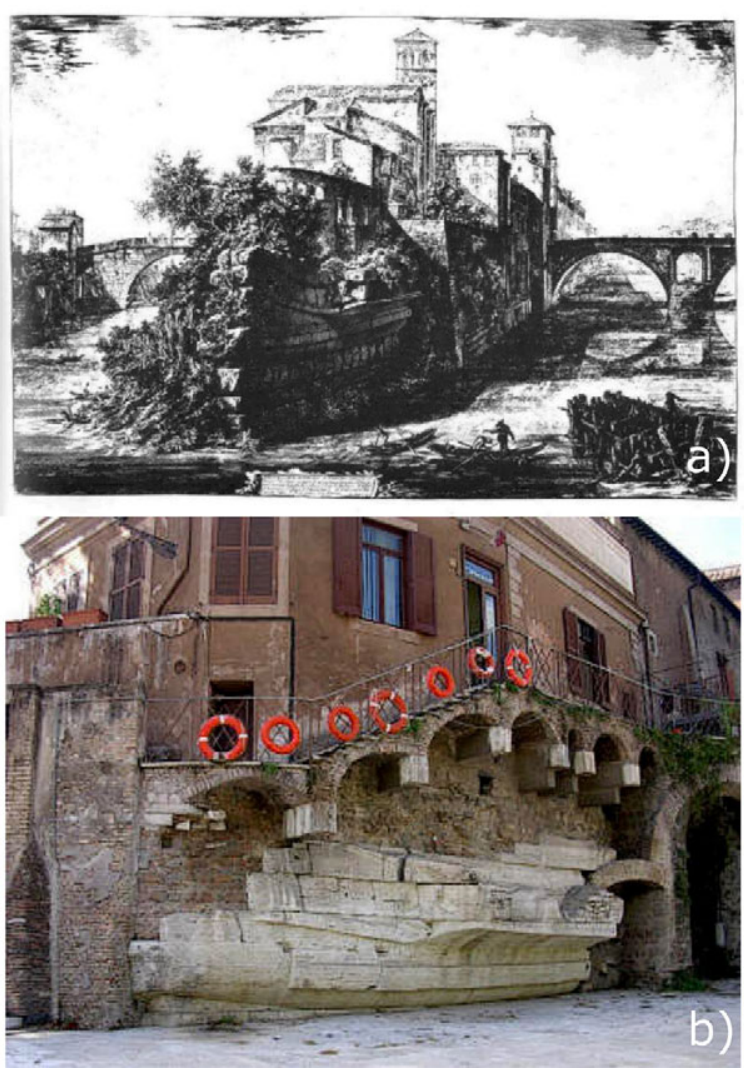

Fig. 4. Tiberina Island geomorphosite, Rome, an example of landform conservation.

a) the boat shaped isle embankments during the Roman period in a painting by G.B. Piranesi (18th century); b) the embankments nowadays (Photo: A. Pica).

audience for urban geotourism, when it relates to the link between historical urban heritage and geological context (e.g., the origin of building stones). However, to our knowledge there is no analysis of the potential public of urban tourism at the moment.

The cities also lend themselves particularly well to study the relationship between geomorphology and urbanization (Pica et al. 2017). Indeed, very often cities have had to adapt to the geomorphological context, which makes it possible to explain the urban form, the network of the communication networks, the location of certain districts or monuments, etc. A geomorphological reading of the urban fabric (Reynard 2017) can be very interesting for tourists visiting a city and can complement the classical urban visits, generally focused on cultural heritage. However, this type of geocultural offer remains very limited at the moment.

Mobile applications (Pica et al. 2017) are particularly suitable in urban areas. Indeed, in an urban context, where panels of all types are already very numerous, the use of educational panels placed on the ground is problematic and often requires long authorization procedures. The good network coverage of mobile telephony as well as the already widespread use of mobile applications for visiting museums advocate the development of applications dedicated to the discovery of urban geology and geomorphology.

\section{Conclusion and research perspectives}

This brief overview of the relationships between geomorphology and urbanization, and various aspects of urban geomorphological heritage, shows that urban contexts have been neglected within geomorphological heritage research in recent decades. Indeed, on the one hand, the interactions between landforms and urbanization are complex and multiple. Their understanding often helps to explain the development of cities, to limit natural risks or to understand the relationships between geomorphological and cultural heritage. On the other hand, studies on the urban geomorphological heritage remain extremely limited. Urban geomorphological maps require an appropriate legend and are very rare. Assessments of geomorphosites are virtually non-existent in urban areas. As for the geotouristic products, they are not really developed compared to what has been done in rural and natural contexts.

More than half of the world's population lives in cities and urban sprawl is very rapid in most countries. In the countries with a long history of urbanization, the works of urban regeneration and recomposition have been particularly important in recent years. In all cases, the development of infrastructure encroaches on the landforms, whose protection is often very weak.

We advocate that geomorphologists undertake comprehensive studies on urban geomorphology, in particular on geomorphological heritage. This requires, as it has already been done in rural and natural environments, the development of specific methods and tools that make it possible to highlight sites of importance and, where appropriate, to enhance them. It is also a matter of bringing together town planning specialists, in particular urban geographers and architects, in 
order to make the geomorphological context an important component of urban projects and, on the other hand, that urban planners are careful to protect, even to enhance, the most emblematic sites (Reynard 2017).

Finally, it seems to us that in addition to the study of already built and urbanized areas, a particular context should be investigated as a priority: urban peripheries. Indeed, it is in these zones, at the interface between the city and the countryside, that the impacts on geomorphology are the most important. It is often in these transition zones that the materials resulting from urbanization (debris) are deposited. It is also there that in the next few years cities will expand, which requires to carry out preliminary investigations in order to protect what deserves it, as archaeologists have done for a very long time. Such analyses would also be very interesting, from a historical perspective, in order to make it possible to compare the pre- and post-urban geomorphology.

\section{Acknowledgements}

We thank Piotr Migoń and Paulo Pereira for their useful comments that allowed us to improve the quality of the manuscript.

\section{References}

Adeli Z., Khorshiddoustb A., 2011. Application of geomorphology in urban planning: Case study in landfill site selection. Procedia Social and Behavioral Sciences 19: 662-667, doi: 10.1016/j.sbspro.2011.05.183

Baud D., Reynard E., 2015. Géohistoire d'une trajectoire paysagère dans la plaine du Rhône valaisan. Analyse du secteur entre Riddes et Martigny (1840-1965) (Geohistory of landscape trajectory in the Rhone River plain. Analysis of the sector Riddes-Martigny (1840-1965)). Norois 237: $15-31$.

Bethemont J., Bravard J.P., 2016. Pour saluer le Rhône (To greet the Rhone River). Libel, Lyon.

Billi A., De Filippis L., Poncia P.P., Sella P., Faccenna C., 2016. Hidden sinkholes and karst cavities in the travertine plateau of a highly-populated geothermal seismic territory (Tivoli, central Italy). Geomorphology 255: 63-80, doi: 10.1016/j.geomorph.2015.12.011

Boivin P., Thouret J.C., 2014. The volcanic Chaîne des Puys: A unique collection of simple and compound monogenetic edifices. In: Fort M., André M.F. (eds), Landscapes and Landforms of France. Springer, Dordrecht: 81-91, doi: 10.1007/978-94-007-7022-5_9

Bondesan A., 2017. Geomorphological processes and landscape evolution of the Lagoon of Venice. In: Soldati M.,
Marchetti M. (eds), Landscapes and Landforms of Italy. Springer International Publishing, Switzerland: 181-191, doi: 10.1007/978-3-319-26194-2_15

Borghi A., d'Atri A., Martire L., Castelli D., Costa E., Dino G., Favero Longo S.E., Ferrando S., Gallo L.M., Giardino M., Groppo C., Piervittori R., Rolfo F., Rossetti P., Vaggelli G., 2014. Fragments of the Western Alpine chain as historic ornamental stones in Turin (Italy): enhancement of urban geological heritage through geotourism. Geoheritage 6: 41-55, doi: 10.1007/s12371-013-0091-7.

Bravard J.P., 1997. Tectonique et dynamique fluviale du Würm à l'Holocène à la confluence Saône-Rhône (France) (Tectonics and fluvial dynamics from Würm to Holocene at the confluence Saône River - Rhone River, France). Géographie physique et Quaternaire 51(3): 315-326.

Brilha J., 2016. Inventory and quantitative assessment of geosites and geodiversity sites: a review. Geoheritage 8(2): 119-134.

Brown A.G., Tooth S., Bullard J.E., Thomas D.S.G., Chiverrell R.C., Plater A.J., Murton J., Thorndycraft V.R., Tarolli P., Rose J., Wainwright J., Downs P., Aalto R., 2017. The geomorphology of the Anthropocene: emergence, status and implications. Earth Surface Processes and Landforms 42: 71-90, doi: 10.1002/esp.3943

Cayla N., 2014. An overview of new technologies applied to the management of geoheritage. Geoheritage 6: 91-102. doi: 10.1007/s12371-014-0113-0

Chin A., 2006. Urban transformation of river landscapes in a global context. Geomorphology 79: 460-487.

Chin A., O’Dowd A.P., Gregory K.J., 2013. Urbanization and river channels. In: Shroder J., Wohl E.E. (eds), Treatise on Geomorphology, Vol. 9, Fluvial Geomorphology. Academic Press, San Diego: 809-827.

Clivaz M., Reynard E., 2017. How to integrate invisible geomorphosites in an inventory: A case study in the Rhone River valley (Switzerland). Geoheritage, doi:10.1007/ s12371-017-0222-7.

Cooke R.U., 1976. Urban geomorphology. Geographical Journal 142: 59-65.

Cooke R.U., 1984. Geomorphological hazards in Los Angeles: A study of slope and sediment problems in a metropolitan county. Allen \& Unwin, London.

Cooke R.U., Brunsden D., Doornkamp J.C., Jones D.K.C., 1982. Urban geomorphology in Drylands. Oxford University Press, Oxford.

Coratza P., Hobléa F., 2017. The specificities of geomorphological heritage. In: Reynard E., Brilha J. (eds), Geoheritage: Assessment, protection, and management. Elsevier, Waltham, in press.

Côté A., Joly M.C., Verner A., 2009). Géotourisme urbain. Le cas de Montréal (Urban geotourism. The case of Montreal). Téoros 28(2): 97-99.

Cousins S.A.O., 2001. Analysis of land-cover transitions based on 17th and 18th century cadastral maps and aerial photographs. Landscape Ecology 16: 41-54, doi:10.1023/A:1008108704358.

Del Lama E.A., de La Corte Bacci D., Martins L., da Glória Motta Garcia M., Kazumi Dehira L., 2015. Urban geotourism and the old centre of São Paulo City, Brazil. Geoheritage 7: 147-164, doi: 10.1007/s12371-014-0119-7.

Del Monte M., Fredi P., Pica A., Vergari F., 2013. Geosites within Rome City center (Italy): a mixture of cultural and geomorphological heritage. Geografia Fisica e Dinamica Quaternaria 36: 241-257, doi: 10.4461/GFDQ.2013.36.0. 
Del Monte M., D’Orefice M., Luberti G.M., Marini R., Pica A., Vergari F., 2016. Geomorphological classification of urban landscapes: the case study of Rome (Italy). Journal of Maps 12: 178-189.

Dóniz-Páez J., Becerra-Ramírez R., 2015. Geoturismo urbano en Puerto de la Cruz (Tenerife, Canarias, España) (Urban geotourism in Puerto de la Cruz). In: Hilario A., Mendia M., Monge-Ganuzas M., Fernández E., Vegas J., Belmonte A. (eds), Patrimonio geológico y geoparques, avances de un camino para todos. Publicaciones del Instituto Geológico y Minero de España, Serie: Cuadernos Del Museo Geominero 18: 347-352.

Douglas I., 2005. The urban geomorphology of Kuala Lumpur. In: Gupta A. (ed.), The Physical Geography of SouthEast Asia. Oxford University Press, Oxford: 344-357.

Douglas I., James P., 2015. Urban ecology. An introduction. Routledge, London.

Douglas I., Lawson N., 2015. The human dimensions of geomorphological work in Britain. Journal of Industrial Ecology 4(2): 9-33.

Dowling R.K., Newsome D. (eds), 2006. Geotourism: sustainability, impacts and management. Elsevier, Oxford.

Ellis E.C., 2011. Anthropogenic transformation of the terrestrial biosphere. Philosophical Transactions of the Royal Society A 369: 1010-1035.

Fernandes N.F., Tupinambá M., Mello C.L., de Peixoto M.N.O., 2010. Rio de Janeiro: A metropolis between granite-gneiss massifs. In: Migoń P. (ed.), Geomorphological landscapes of the World. Springer, Dordrecht: 89-100.

Gierlinger S., Haidvogel G., Gingrich S., Krausmann F., 2013. Feeding and cleaning the city: the role of the urban waterscape in provision and disposal in Vienna during the industrial transformation. Water History 5: 219-239.

Gomez-Heras M., Smith B.J., Viles H.A., 2010. Oxford stone revisited: causes and consequences of diversity in building limestone used in the historic centre of Oxford, England. In: Přikryl R., Török Á (eds), Natural stone resources for historical monuments. The Geological Society, London, Special Publications 333: 101-110.

Gordon J.E., Barron H.F., Hansom J.D., Thomas, M.F., 2012. Engaging with geodiversity - why it matters. Proceedings of the Geologists' Association 123: 1-6.

Goudie A.S., Viles H.A., 2016. Geomorphology in the Anthropocene. Cambridge University Press, Cambridge.

Grandgirard V., 1997. Géomorphologie, protection de la nature et gestion du paysage (Geomorphology, nature protection and landscape management). PhD Thesis in Geography, University of Fribourg.

Gray M., Gordon J.E., Brown E.J., 2013. Geodiversity and the ecosystem approach - the contribution of geoscience in delivering integrated environmental management. Proceedings of the Geologists' Association 124: 659-73.

Gross M., Zimmerman R., 2002. Interpretive centers. The history, design, and development of nature and visitor centers. UW-SP Foundation Press, Stevens Point.

Haidvogel G., Guthyne-Horvath M., Gierlinger S., Hohensinner S., Sonnlechner C., 2013. Urban land for a growing city at the banks of a moving river: Vienna's spread into the Danube island Unterer Werd from the late 17th to the beginning of the 20th century. Water History 5: 195-217.

Halsall T.J., 2000. Geological constraints on the siting of fortifications: examples from medieval Britain. In: Rose E.P.F., Nathanail C.P. (eds), Geology and warfare: Examples of the influence of terrain and geologists on military operations. The Geological Society, London: 3-31.
Hohensinner S., Sonnlechner C., Schmid M., Winiwarter V., 2013a. Two steps back, one step forward: reconstructing the dynamic Danube riverscape under human influence in Vienna. Water History 5: 121-143.

Hohensinner S., Lager B., Sonnlechner C., Haidvogel G., Gierlinger S., Schmid M., Krausmann F., Winiwarter V., 2013b. Changes in water and land: the reconstructed Viennese riverscape from 1500 to the present. Water History 5: $145-172$.

Hose T.A., 1995. Selling the story of Britain's stone. Environmental Interpretation 10(2): 16-17.

Hose T.A, 2012. 3G's for modern geotourism. Geoheritage 4: $7-24$.

James L.A., Hodgson M.E., Ghoshal S., Latiolais M.M., 2012. Geomorphic change detection using historic maps and DEM differencing: The temporal dimension of geospatial analysis. Geomorphology 137: 181-198, doi:10.1016/j.geomorph.2010.10.039.

Jamot C., 2001. Clermont-Ferrand. Mappemonde 64: 30-35.

Jordan H., Hamilton K., Lawley R., Price S.J., 2014. Anthropogenic contribution to the geological and geomorphological record: A case study from Great Yarmouth, Norfolk, UK. Geomorphology 253: 534-546.

Kasprzak M., Traczyk A., 2014. LiDAR and 2D Electrical Resistivity Tomography as a supplement of geomorphological investigations in urban areas: a case study from the City of Wrocław (SW Poland). Pure and Applied Geophysics 171: 835-855.

Lamich D., Marschalko M., Yilmaz I., Bednářová P., Niemiec D., Durd'ák J., Kubečka K., Duda R., 2016. Utilization of engineering geology in geo-tourism: few case studies of subsidence influence on historical churches in Ostrava-Karvina District (Czech Republic). Environmental Earth Sciences 75: 128, doi: 10.1007/s12665-015-4993-3

Lave R., Wilson M.W., Barron E.S., Biermann C., Carey M.A., Duvall C.S., Johnson L., Lane K.M., McClintock N., Munroe D., Pain R., Proctor J., Rhoads B.L., Robertson M.M., Rossi J., Sayre N.F., Simon G., Tadaki M., Van Dyke C., 2014. Intervention: Critical physical geography. The Canadian Geographer 58: 1-10, doi: 10.1111/cag.12061

Li P., Qian H., Wu J., 2014. Accelerate research on land creation. Nature 510: 29-31.

Lucchesi S., Giardino M., 2015. Historical archives data for the reconstruction of geomorphological modifications in the urban area of Turin (NW Italy). In: Lollino G. et al. (eds), Engineering geology for society and territory, vol. 8. Springer International Publishing, Switzerland: 447-452, doi:10.1007/978-3-319-09408-3_46.

Martin S., 2014. Interactive visual media for geomorphological heritage interpretation. Theoretical approach and examples. Geoheritage 6(2): 149-157.

Martin S., Regolini-Bissig G., Perret A., Kozlik L., 2010. Elaboration et évaluation de produits géotouristiques. Propositions méthodologiques (Elaboration and evaluation of geotouristic products. Methodological proposals). Téoros 29(2): 55-66.

Martin S., Reynard E., Pellitero Ondicol R., Ghiraldi L., 2014. Multi-scale web mapping for geoheritage visualisation and promotion. Geoheritage 6: 141-148.

Martín-Díaz J., Nofre J., Oliva M., Palma P., 2011. Geomorphological risks, suburbanisation and neoliberalisation of the urban space in post-war Sarajevo. Area 47:371-378.

McCall G.J.H., De Mulder E.F.J., Marker B.R., 1996. Urban Geoscience. Balkema, Rotterdam. 
Meadows M.E., Compton J.S., 2015. Table Mountain: Wonder of nature at the foot of Africa. In: Grab S., Knight J. (eds), Landscapes and landforms of South Africa. Springer International Publishing, Switzerland: 95-102.

Migoń P., Pijet-Migoń E., 2017. Viewpoint geosites - values, conservation and management issues. Proceedings of the Geologists' Association, doi:10.1016/j.pgeola.2017.05.007

Mohapatra S.N., Pani P., Sharma M., 2014. Rapid urban expansion and its implications on geomorphology: A remote sensing and GIS based study. Geography Journal 2014: ID 361459, doi: 10.1155/2014/361459.

Moscariello A., 2017. The geomorphological landscapes in the Geneva Basin. In: Reynard E. (ed.), Landscapes and Landforms of Switzerland. Springer International Publishing, Switzerland, in press.

Mozzi P., Fontana A., Ferrarese F., Ninfo A., Campana S., Francese R., 2016. The Roman City of Altinum, Venice Lagoon, from remote sensing and geophysical prospection. Archaeol. Prospect. 23: 27-44, doi:10.1002/arp.1520

Onde H., 1966. Réflexions sur quelques sites urbains (Reflections on some urban sites). Cahiers de géographie de Besançon 14: 107-113.

Ortega-Guerrero A., Rudolph D.L., Cherry J.A., 1999. Analysis of long-term land subsidence near Mexico City: Field investigations and predictive modeling. Water Resources Research 35(11): 3327-3341, doi: 10.1029/1999WR900148

Ortiz-Zamora D., Ortega-Guerrero A., 2010. Evolution of long-term land subsidence near Mexico City: Review, field investigations, and predictive simulations. Water Resources Research 46: W01513, doi: 10.1029/2008WR007398

Panizza M., 2001. Geomorphosites: concepts, methods and example of geomorphological survey. Chinese Science Bulletin 46, Suppl. Bd: 4-6.

Palacio-Prieto J.L., 2015. Geoheritage within cities: Urban geosites in Mexico City. Geoheritage 7: 365-373, doi:10.1007/s12371-014-0136-6

Pelfini M., Bollati I., 2014. Landforms and geomorphosites ongoing changes: Concepts and implications for geoheritage promotion. Quaestiones Geographicae 33(1): 131-143.

Perez-Monserrat E.M., Buergo M.A., Gomes-Heras M., Muriel M.J.V., Gonzalez R.F., 2013. An urban geomonumental route focusing on the petrological and decay features of traditional building stones used in Madrid, Spain. Environmental Earth Sciences 69: 1071-1084.

Pica A., Vergari F., Fredi P., Del Monte M., 2016. The Aeterna Urbs geomorphological heritage (Rome, Italy). Geoheritage 8(1): 31-42, doi: 10.1007/s12371-015-0150-3

Pica A., Reynard E., Grangier L., Kaiser C., Ghiraldi L., Perotti L., Del Monte M., 2017. GeoGuides, urban geotourism offer powered by mobile application technology. Geoheritage, doi: 10.1007/s12371-017-0237-0

Pickett S.T.A., Cadenasso M.L., Grove J.M., Nilon C.H., Pouyat R.V., Zipperer W.C., Costanza R., 2001. Urban ecological systems: Linking terrestrial ecological, physical, and socioeconomic components of metropolitan areas. Annu. Rev. Ecol. Syst. 32: 127-157.

Price S.J., Ford J.R., Cooper A.H., Neal C., 2011. Humans as major geological and geomorphological agents in the Anthropocene: the significance of artificial ground in Great Britain. Philosophical Transactions of the Royal Society A 369: 1056-1084.

Přikryl R., Török Á. (eds), 2010. Natural stone resources for historical monuments. The Geological Society, London.
Reynard E., 2005a. Géomorphosites et paysage (Geomorphosites and Landscape). Géomorphologie: relief, processus, environnement 3: 181-188.

Reynard E., 2005b. Geomorphological sites, public policies and property rights. Conceptualization and examples from Switzerland. Il Quaternario 18(1): 321-330.

Reynard E., 2009. Geomorphosites: definitions and characteristics. In: Reynard E., Coratza P., Regolini-Bissig G. (eds), Geomorphosites. Pfeil Verlag, München: 9-20.

Reynard E., 2017. La géomorphologie urbaine au service du projet (Urban geomorphology at the service of the project). In: Delabarre M., Dugua B. (eds), Faire la ville par le projet. Presses polytechniques et universitaires romandes, Lausanne: 185-203.

Reynard E., Coratza P., 2013. Scientific research on geomorphosites. A review of the activities of the IAG working group on geomorphosites over the last twelve years. Geogr. Fis. Dinam. Quat. 36: 159-168.

Reynard E., Coratza P., Regolini-Bissig G. (eds.), 2009. Geomorphosites. Pfeil Verlag, München.

Reynard E., Hobléa F., Cayla N., Gauchon C., 2011. Iconic sites for Alpine geology and geomorphology. Rediscovering heritage?. Revue de Géographie Alpine | Journal of Alpine Research [on-line], 99(2), doi: 10.4000/rga.1435

Reynard E., Kaiser C., Martin S., Regolini G., 2015. An application for Geosciences communication by smartphones and tablets. In: Lollino G. et al. (eds), Engineering geology for society and territory, vol. 8. Springer International Publishing, Switzerland: 265-268, doi:10.1007/978-3319-09408-3_46

Robinson E., 1982. A geological walk around the City of London - royal exchange to Aldgate. Proceedings of the Geologists' Association 93: 225-246.

Robinson E., 1984. London: illustrated geological walks, vol. 1. Scottish Academic Press, Edinburgh.

Robinson E., 1985. London: illustrated geological walks, vol. 2. Scottish Academic Press, Edinburgh.

Rodrigues M.L., Machado C.R., Freire E., 2011. Geotourism routes in urban areas: a preliminary approach to the Lisbon geoheritage survey. GeoJournal of Tourism and Geosites 8(2): 281-294.

San-Antonio-Gómez C., Velilla C., Manzano-Agugliaro F., 2014. Urban and landscape changes through historical maps: The Real Sitio of Aranjuez (1775-2005), a case study. Computers, Environment and Urban Systems 44: 47-58.

Schneider A., Fried M.A., Potere D., 2009. A new map of global urban extent from MODIS satellite data. Environmental Research Letters 4: 1-11.

Sherlock R.L., 1922. Man as a geological agent: an account of his action on inanimate nature. Whitherby, London.

Shimizu, E., Fuse T., 2003. Rubber-sheeting of historical maps in GIS and its application to landscape visualization of old-time cities: focusing on Tokyo of the past. Proceedings of the 8th International Conference on Computers in Urban Planning and Urban Management, 11A-3, CDROM.

Siles G.L., Alcérreca-Huert, J.C., López-Quiroz P., Niemeier W., 2015. Long term subsidence analysis and soil fracturing zonation based on InSAR time series modelling in Northern Zona Metropolitana del Valle de Mexico. Remote Sensing 7: 6908-6931, doi: 10.3390/rs70606908

Sivaplan M., Savenije H.H.G., Blöschl G., 2012. Socio-hydrology: A new science of people and water. Hydrological Processes 26(8): 1270-1276, doi: 10.1002/hyp.8426 
Smith M., Paron P., Griffiths J., 2011. Geomorphological mapping. Methods and applications. Elsevier, Amsterdam.

Steffen W., Grinevald J., Crutzen P., McNeill J., 2011. The Anthropocene: conceptual and historical perspectives. Philosophical Transactions of the Royal Society A 369: 842-867.

Szabó J., Dávid L., Loczy D. (eds), 2010. Anthropogenic geomorphology: A guide to Man-made landforms. Springer, Dordrecht.

Stäuble S., Martin S., Reynard E., 2008. Historical mapping for landscape reconstruction: examples from the Canton of Valais (Switzerland). In: Mountain Mapping and Visualisation. Proceedings of the 6th ICA Mountain Cartography Workshop, 11-15 February 2008, Lenk, Switzerland: 211-217.

Tarolli P., Sofia G., 2016. Human topographic signatures and derived geomorphic processes across landscapes. Geomorphology 255: 140-161.

Thornbush M., 2015. Geography, urban geomorphology and sustainability. Area 47: 350-353.

Tilden F., 1957. Interpreting our heritage. The University of North Carolina Press, Chapel Hill.
Valette P., Carozza J.M., 2013. Toulouse face à la Garonne: emprise de l'urbanisation dans la plaine inondable et géohistoire des aménagements fluviaux (Toulouse facing the Garonne River: influence of urbanization in the floodplain and geohistory of river developments). Geographicalia 63-64: 77-203.

Wilczkiewicz M.Z., 2016. The role of artificial landscape in recreational parks - selected examples. Geomatics, Landmanagement and Landscape 1: 105-117, doi: 10.15576/ GLL/2016.1.105

Williams D.B., 2015. Too high and too steep. Reshaping Seattle's topography. University of Washington Press, Seattle.

Winiwarter V., Schmid M., Dressel G., 2013a. Looking at half a millennium of co-existence: the Danube in Vienna as a socio-natural site. Water History 5: 101-119.

Wolman M.G., 1967. A cycle of sedimentation and erosion in urban river channels. Geografiska Annaler: Series A, Physical Geography 49: 385-395.

Yamaguchi K., Nakajima I., Kawasaki M., 2008. The application of the surrounding landform to the landscape design in japanese gardens. WSEAS Transactions on Environment and Development 8(4): 655-665. 